\title{
The Application of CALL in College English Writing Teaching
}

\author{
Hong-cai YAN $^{1, a}$ and Yin-qiu SONG ${ }^{1,2, b, ~ * ~}$ \\ ${ }^{1}$ Jilin Agricultural University, Changchun, P.R. China \\ ${ }^{2}$ Northeast Normal University, Changchun, P.R. China \\ a1121846092@qq.com, b914008287@qq.com \\ ${ }^{*}$ Corresponding author
}

Keywords: CALL, College English, Writing, Internet.

\begin{abstract}
Information age exerts great influence on education and teaching. With the changes of students' learning goals and pluralism of their learning methods and modes, the introduction of computer-aided and network-based teaching model to college English instruction becomes a necessity. An experiment was designed and conducted to study the effectiveness of CALL in improving students' English writing ability. The computer-aided writing teaching model used is the integration of the face-to-face teaching model (using multi-media classrooms and computer labs), and the autonomous learning model (students' attending network-based writing class). 16 natural classes (475 students) from Jilin Agricultural University were chosen randomly to participate in the two-year experiment, among which 8 experimental classes (238 students) were taught with the application of CALL while the other 8 control classes (237 students) with traditional teaching method (without the application of CALL). The achievements of the experimental students are significantly higher than those of the control in each of the four terms. The results indicate that the experimental students' autonomous learning ability is improved and their learning efficiency is enhanced. It follows that CALL is an effective approach to improve students' English writing ability.
\end{abstract}

\section{Introduction}

Global economization and social informationization make English, a major international communication language, increasingly important, which put forward higher requirements on modern English instruction. As an essential writing skill, English writing is not merely a way for people to express their ideas, but also a reflection of their English comprehensive ability.

The traditional writing teaching ignores the subjective initiative of students' interaction, consultation and supervision in their pre-writing, in-writing and post-writing; students are extremely passive and lack of active, positive psychology of writing in the whole writing process. Thus they lack of writing motivation and the real purpose of communication, and the low writing ability can be easily imagined.

CNAWI (Computer \& Net-work Aided Writing Instruction) is a very important application field of computer and using CNAEWI (Computer \& Net-work Aided English Writing Instruction) has great potential. Computer \& Net-work, which have the rich resources and the strong interaction, becomes the effective teaching tools with taking the student as the main body and through communicative language learning. CNAEWI truly advocates the students active participation, willing exploration and diligent hands, train students the ability of collecting and processing information, 
obtaining new knowledge, and analyzing and solving problems. It has changed the single information transmission of former English writing teaching and the individual feedback channel, and effectively aroused students' enthusiasm for English writing.

\section{Theoretic Basis}

\section{The theory of Constructivism}

Constructivism is a psychological theory of knowledge which argues that humans construct knowledge and meaning from their experiences.

Formalization of theory of constructivism is generally attributed to Jean Piaget, who (1973) [1] articulated mechanisms by which knowledge is internalized by learners. He suggested that through process of accommodation and assimilation, individuals construct new knowledge from their experiences. When individuals assimilate, they incorporate the new experience into an already existing framework without changing that framework. This may occur when individuals' experiences are aligned with their internal representations of the world, but may also occur as a failure to change a faulty understanding In contrast, when individuals' experiences contradict their internal representations, they may change their perceptions of the experiences to fit their internal representations.

\section{The Theory of Autonomous Learning}

The Concept of Autonomous Learning. The concept "autonomous learning" stemmed from debates about the development of life-long learning skills and the development of independent thinkers both of which originated in the 1960s. By 1981, Holec (1983) had defined autonomy as "the ability to take charge of one's own learning" [2]. Dickenson (1987) accepted the definition of autonomy as a "situation in which the learner is totally for all of autonomy decision concerned with his (or her) learning and the implementation of those decisions [3]. An example of viewing autonomy as an educational practice comes from Bound (1988) who suggested that, as well as being educational goal autonomy is "an approach to educational practice" [4]. Cardner and Miller (1999) defined autonomous learning as those who "initiate the planning and implementation of their own learning program" [5].

The Role of Teachers in Autonomous Learning. It is a misunderstanding that teachers need not exist in autonomous learning. Instead, autonomous learning has new and high demand for teachers, which needs to reposition teachers' role. Teachers are the keys to create an autonomous atmosphere in classroom. Autonomous learning relies on the benign interaction of teachers and their students, which require teachers to often organize, instruct, guide, inspire and encourage their students to learn autonomously [6]. So teachers should provide enough learning resources for their students, timely instruct their students when they have difficulties or problems during their learning, guide students to master scientific learning methods, and train students to have the abilities of analysis, induction, comparison, comprehensiveness and summary. In addition, in the autonomous learning mode, teachers must clearly understand that college English teaching is a systematic whole in which the process includes not merely classroom teaching but also after-class autonomous learning and tutoring; after-class autonomous learning, whose effect is especially important, is the consolidation, extension and expansion of classroom teaching $[7,8]$. 
The Role of Students in Autonomous Learning. Students should change their passive situation to active situation, take charge of their learning and be a master of their study. They should change their attitudes and transfer from "They want me to learn" to "I want to learn". Students may decide their content and speed, monitor their study process, and evaluate their study effect. Students need to become more aware of their central role in decision-making process. Students become planners of their own learning, assessors of themselves and others, evaluators of autonomous learning, motivators of themselves, administrators and organizers of their own learning, and advisors to other learners. They have to learn about the importance of reflection on their learning and how it can help them to redefine their goals to make them consistently relevant to their needs.

\title{
Process-writing Teaching Method
}

Process writing is an approach to incorporating writing skills from the very beginning of the English learning process. It was developed by Gail Heald-Taylor in her book Whole Language Strategies for ESL Students [9]. Process writing focuses on allowing students - especially young learners - to write with plenty of room left for error. Standard correction begins slowly, and children are encouraged to communicate through writing, despite limited understanding of structure.

Process writing can also be used in an adult ESL / EFL setting to encourage learners to start working on their writing skills from a beginning level. If you are teaching adults, the first thing learners need to understand is that their writing skills will be well below their native language writing skills. This seems rather obvious, but adults are often hesitant to produce written - or spoken - work that is not up to the same level as their native language skills. By easing your students' fears about producing sub-par written work, you can help encourage them to improve their writing abilities.

\begin{abstract}
Aim
The aim of our experiment is to optimize English writing teaching process, improve the teaching quality and efficiency, students' writing ability and overall quality by means of CNAWI (Computer \& Net-work Aided Writing Instruction).

Our experiment is also to explore solutions to the problems of time-consuming and inefficiency, being weary of teaching and studying caused by an inadequate amount of language input and a single teaching method in college English writing. And we hope our teaching mode can effectively evoke teachers' and students' enthusiasm of their teaching and learning towards English writing, and improve students' English writing ability and level.
\end{abstract}

\section{Procedure}

\section{Subject of Study}

475 students from 16 natural classes of Grade 2010 in Jilin Agricultural University are chosen randomly to participate in the two-year experiment, among which 8 experimental classes (238 students) and the other 8 control classes (237 students).

\section{Investigation}

A diagnostic investigation are carried out to know students' achievements of their college entrance examination, and students' structure (coming from rural areas or urban 
cities); an English proficiency test and a vocabulary test are conducted to determine whether the experimental classes and the control classes are comparable.

\section{Implementation}

CNAWI (Computer \& Net-work Aided Writing Instruction) is implemented in the 8 experimental classes. Specific methods are as follows:

Establish a New Network Writing Mode. Students and their teachers can use the computer network of QQ group, electronic forum, blog, electronic submission. Teachers and students together provide writing content which they are all interested in. Students hold free discussions, determined their writing topics and outlines, make arguments about how to write, and they can complement each other after their summary. Students can sum up their strengths and weaknesses in the process of making mental preparations, learn some good methods and perspectives from other students or teachers, thus form their respective articles

Establish a Network Writing Mode of Reading and Writing Combination. Using e-mails and network writing center, teachers or students all can provide rich, beautiful, authentic articles or model essays for student' reading. Reading is the foundation and source for writing. Students are able to understand and master words, sentence patterns and discourse structures through reading, and sum up their own logical thinking methods, thus their writing skills and abilities are improved. Combination of reading and writing can also analyze and study texts and students' exercises.

Establish Network Writing Interactive Teaching Mode. Students can use one or several of the various forms of computer \& network aided English writing instruction mode to encourage their own active learning. And they have no shyness of facing their teachers and classmates, so they haven't any psychological anxiety; as a result, their conscious learning abilities are improved. Teachers and students learn and advise each other, thus, one can not only get his classmate's and teachers' comments on his article, but also learn a lot of knowledge from his classmate's and teachers' opinions and suggestions.

Establish a Mechanism of Electronic Exchange between Students and Their Domestic and Foreign Pen Pals In Extracurricular. Electronic exchange with foreign pen pals on the internet: Teachers collect some pen pal addresses on the net and help students fix an authentic language exchange pen pal. Through E-mails, students conduct in English natural, authentic and meaningful written exchange activities.

Electronic exchange among students on the school network: Teachers create opportunities and conditions for students by employing the school network or the local area network. Through E-Mils, Students in two classes of the same school conduct natural and authentic written exchanges.

Extracurricular electronic discussion on the school network: Firstly, establish on the school network a mailing list for the class, or a special news group. The teacher then can make full use of them, publishing the content of the coming class in the news group and instructing students to carry out discussions on them in English.

Establish an Online Peer Feedback Mode. In the process of evaluating and proofreading, we employ the evaluating mechanism of "one composition three drafts". The system integrates organically "peer mutual assessment" and "teacher assessment". Students upload their first drafts onto their peers' mutual assessing module, first mutually evaluating the compositions on linguistic level with the aid of the net database, and then returning the e-drafts to their authors. Based on peers' assessment, the authors 
reread and reflect on their works, and then complete the second drafts. This time, students upload their revised compositions onto their teachers' assessing module. After evaluating, teachers return them to the authors for the second revision, and students complete their final drafts. Students can upload the final drafts onto the model essay appreciating module for public reading and assessing, and simultaneously consulting other students' works. By inspecting, emulating and comparing, students are able to find advantages and disadvantages of their own writing.

Establish an Online College English Writing Platform. Based on the needs of the writing model, we first improve the Experience College English Autonomous Learning System, inserting extranet interface, accomplishing the abutment of the learning platform with the BNC online database and other related online databases, perfecting the function of data uploading and sharing, which makes no-barrier information resources sharing between teachers and students available. Meanwhile, we add more functional modules, and establish college English writing platform.

The writing teaching platform contains five functional modules: online resources module, teacher and student interactive module, information releasing module, homework submission and feedback module, model essay appreciation module.

CNAWI (Computer \& Net-work Aided Writing Instruction) is not actively implemented in the 8 control classes while traditional writing teaching method (a single directional pattern of students individually writing and teacher alone review) is carried out in them.

\section{Assessment and Evaluation}

At the end of each term, students of experimental and control classes are assessed and evaluated on their writing and comprehensive abilities and a model CET4 is implemented in them. At the 4th term, the rate of CET4 and the awards within two years are compared between the experimental and the control classes

\section{Result and Discussion}

\section{Diagnostic Investigation}

The students' English basis is very important to their future English study. In general, students have a good English basis at enrollment, their progress in English learning will be faster in the future; conversely, if students have a poor English basis at enrollment, their progress in English learning will be slower in the future [10]. If there is a remarkable disparity between the students of experimental and control classes, they will lose their comparability, which will be unable to ensure the reliability of the experiment.

Table 1 shows that there are no significant differences in the students' English achievements of their college entrance examination, the students' achievements of English proficiency test, the students' vocabularies, the proportions of urban and rural students between the experimental and the control classes. This explains that there is no significant difference in basic conditions of students between the experimental and the control classes. Therefore they are comparable and the reliability can be ensured. 
Table 1. Comparison of basic conditions between the students

in the experimental and the control classes

\begin{tabular}{|c|c|c|c|c|c|c|}
\hline Class & number of & scores of & Scores of & Vocabulary & \multicolumn{2}{c|}{ Proportion of students } \\
\hline & students & CEE & EPT & & Urban (\%) & Rural (\%) \\
\hline Experimental class & 238 & 105.4 & 51.8 & 1758 & 49.6 & 50.4 \\
\hline Control class & 237 & 106.1 & 52.2 & 1760 & 48.9 & 51.1 \\
\hline $\begin{array}{c}\text { Significant } \\
\text { difference (5\%) }\end{array}$ & & n. s. & n. s. & n. s. & n. s. & n. s. \\
\hline
\end{tabular}

Note: n.s.(no significance) shows that there is no significant difference between the two numbers in the same column; CET: college entrance examination; EPT: English proficiency test.

\section{English Achievement}

Table 2 shows that the students' average achievement of the experimental classes in each term is significantly higher than that of the control classes. For example, the students' average achievement is 9 scores higher than that of the control classes in the 4th term; the students' average final examination achievement is 10 scores higher than that of the control classes in the 4th term; the students' average model CET4 achievement is 8 scores higher than that of the control classes in the 4th term. From the results mentioned above, we can conclude that CNAWI is effective and promote students' English language ability.

\begin{tabular}{|c|c|c|c|c|c|c|c|c|c|c|c|c|c|}
\hline \multicolumn{14}{|c|}{ Table 2. The comparis on of students' average English achievements } \\
\hline \multicolumn{14}{|c|}{ between the experimental classes and the control classes in four terms } \\
\hline \multirow[t]{2}{*}{ Class } & \multirow{2}{*}{$\begin{array}{c}\text { number of } \\
\text { students }\end{array}$} & \multicolumn{4}{|c|}{ Scores of writing } & \multicolumn{4}{|c|}{ Socores of final exam } & \multicolumn{4}{|c|}{ Scores of model CET4 } \\
\hline & & Terml & Term2 & Term3 & Term4 & Term1 & Term2 & Term3 & Term4 & Term1 & Term2 & Term? & Term4 \\
\hline Experimental class & 238 & 64 & 68 & 73 & 80 & 62 & 68 & 74 & 78 & 48 & 54 & 58 & 61 \\
\hline Control class & 237 & 57 & 60 & 66 & 71 & 54 & 60 & 64 & 68 & 40 & 45 & 47 & 53 \\
\hline Significant & & \multirow{2}{*}{ s. } & \multirow{2}{*}{ s. } & \multirow{2}{*}{ s. } & \multirow{2}{*}{ s. } & \multirow{2}{*}{ s. } & \multirow{2}{*}{ s. } & \multirow{2}{*}{ s. } & \multirow{2}{*}{ s. } & \multirow{2}{*}{ s. } & \multirow{2}{*}{ s. } & \multirow{2}{*}{ s. } & \multirow{2}{*}{ s. } \\
\hline difference $(5 \%)$ & & & & & & & & & & & & & \\
\hline
\end{tabular}

Note: s. (significance) shows that there is no significant difference between the two numbers in the same column.

In the two years, the students in experimental and control classes take part in the university-level English writing contest two times. The students in the experimental classes, two students win first prize, 5 students win second prize, seven students win third prize; while the students in the control classes, only two students win third prize. In the National English Contest for College Students they attend two times, the students in the experimental classes, one student wins first prize, three students win second prize, five students win third prize, while the students in the control classes, only one student wins third prize. In the CET4 they attend two times, the rate of the students in the experimental classes who have got the scores over 425 is $62 \%$, while the rate of the students in the control classes who have got the scores over 425 is only $50 \%$. The results mentioned above show that CNAWI is effective and promote students' English comprehensive application ability from the other side.

\section{Conclusion}

After two-year exploration and practice, The Application of CALL in College English Writing Teaching (that is CNAWI) has achieved remarkable results. We can conclude 
that: (1) it favorably improves the enthusiasm of the students writing, stimulate their interest, effectively improves their English writing ability; (2) it provides vivid and rich teaching resources for teachers and students, expands the space of learning and realizes the continuity sharing of English writing resources; (3) it favorably teaches students in accordance with their aptitude, realizes the students' personalized learning, and cultivate students' language-using and autonomous learning ability; (4) it changes the teachers' traditional role and makes the relationship between teachers and students more harmonious; (5) it enhances students' English comprehensive application ability.

\section{Acknowledgement}

This research was financially supported by the Twelfth Five-Year Plan Project Foundation of Jilin Provincial Teaching and Education (GH14153).

\section{References}

[1] J. Piaget. To Understand is to Invent. New York: Grossman, 1973.

[2] H. Holec. Autonomy in Foreign Language Learning. Oxford: Pergamon, 1983.

[3] L. Dickinson. Self-instruction in Language Learning. Cambridge: Cambridge University Press, 1987.

[4] D. Bound. Developing Student Autonomy in Learning. London: Kogan Page, 1988.

[5] D. Gardner and L. Miller. Establishing Self-Access: From Theory to Practice. Cambridge University Press, 1999.

[6] X.Q. Li. On Cultivation of Autonomous-Learning Ability in College English, Theory and Practice of Education, Vol. 29, pp. 42-45, 2009. (In Chinese)

[7] S. M. Shu. To Arouse the Students' Autonomy Is the Key to Speed up the Input to Output Process, Foreign Language Teaching, No. 2, pp. 95-97, 2003. (In Chinese)

Z.W. Wang. An Analysis of College English Autonomous Learning, Journal of Anhui University of Science and Technology (Social Science Edition), No. 4, pp. 95-96, 2003. (In Chinese)

G. Heald-Taylor. Whole Language Strategies for ESL Students. Carlsbad: Dominie Press, Inc., 1994.

H. C. Yan and Y. Q. Song. Study on the Independent Innovation Learning Model of College English Multi-dimensional Integration Theme-based Teaching, Modern Education Science, No. 1, 72-75, 2011. (In Chinese) 